OPEN ACCESS

Edited by:

Georg Böhmig,

Medical University of Vienna, Austria

Reviewed by:

Nils Lachmann,

Charité-Universitätsmedizin

Berlin, Germany

Markus Wahrmann

Medical University of Vienna, Austria

*Correspondence:

Stefan Schaub

stefan.schaub@usb.ch

orcid.org/0000-0002-9170-1341

Specialty section:

This article was submitted to

Nephrology,

a section of the journal

Frontiers in Medicine

Received: 14 June 2021

Accepted: 08 July 2021

Published: 02 August 2021

Citation:

Senn L, Wehmeier C, Hönger G, Geiger I, Amico P, Hirt-Minkowski P.

Steiger J, Dickenmann M and

Schaub S (2021) Outcome of

Husband-to-Wife Kidney

Transplantation With Mutual Children:

Single Center Experience Using T Cell-Depleting Induction and Review of

the Literature. Front. Med. 8:724851.

doi: 10.3389/fmed.2021.724851

\section{Outcome of Husband-to-Wife Kidney Transplantation With Mutual Children: Single Center Experience Using $T$ Cell-Depleting Induction and Review of the Literature}

\author{
Lisa Senn ${ }^{1}$, Caroline Wehmeier ${ }^{1}$, Gideon Hönger ${ }^{1,2,3}$, Irene Geiger ${ }^{1}$, Patrizia Amico', \\ Patricia Hirt-Minkowski ${ }^{1}$, Jürg Steiger ${ }^{1}$, Michael Dickenmann ${ }^{1}$ and Stefan Schaub ${ }^{1,2,3 *}$ \\ ${ }^{1}$ Clinic for Transplantation Immunology and Nephrology, University Hospital Basel, Basel, Switzerland, ${ }^{2}$ HLA-Diagnostics and \\ Immungenetics, Department of Laboratory Medicine, University Hospital Basel, Basel, Switzerland, ${ }^{3}$ Transplantation \\ Immunology, Department of Biomedicine, University of Basel, Basel, Switzerland
}

Few data on husband-to-wife transplantations with mutual children $(\mathrm{H} 2 \mathrm{~W})$ exist in the current era. We investigated the outcome of $\mathrm{H} 2 \mathrm{~W}$ transplantations $(n=25)$ treated with $T$ cell-depleting induction compared to women with prior pregnancies also receiving their first HLA-mismatched kidney transplant, but from a different donor source: (i) other living donor $(n=52)$ and (ii) deceased donor $(n=120)$. Seventy-four percent of the women had $\geq 2$ pregnancies; median follow-up time was 5 years. Death-censored allograft survival was significantly lower in the $\mathrm{H} 2 \mathrm{~W}$ group compared to the other two groups ( $p=0.03$ ). Three of four graft losses in the H2W group were due to rejection. 5-year patient survival in the $\mathrm{H} 2 \mathrm{~W}$ group was high and similar compared to the other living donor group (100 vs. $98 \% ; p=0.28$ ). The incidence of (sub)clinical antibody-mediated rejection was higher in the H2W group (36 vs. 20 vs. 18\%) $(p=0.10)$. The frequency of infections was similar among the three groups. No immunological parameter was predictive for rejection or graft loss in $\mathrm{H} 2 \mathrm{~W}$ transplantations. In conclusion, $\mathrm{H} 2 \mathrm{~W}$ transplantation is a valuable option, but associated with a higher risk for allograft loss due to rejection despite $T$ cell-depleting induction. Further research is required for better risk prediction on an individual patient level.

Keywords: husband-to-wife transplantation, kidney transplantation, allograft rejection, infection, pregnancyinduced sensitization

\section{INTRODUCTION}

Pregnancy is an important reason for HLA-directed sensitization. Using sensitive single antigen bead assays on the Luminex platform, child-specific HLA-directed antibodies are detected immediately after delivery in about $20-30 \%$ of women after one pregnancy and almost $50 \%$ after three or more pregnancies (1). This suggests that repeated exposures to the same HLA molecules increases the likelihood of a detectable humoral immune response $(2,3)$. Furthermore, it is wellknown that pregnancy-induced HLA antibodies can diminish over time, while alloreactive T- and B cells still persist (4). 
Many women evaluated for kidney transplantation had prior pregnancies more than $10-20$ years ago $(5,6)$. As sera dating back to the immediate time after delivery are very rarely available, sensitization cannot be excluded, even if no HLA antibodies are detectable in current sera. This is a major diagnostic challenge in husband-to-wife transplantations with mutual children (H2W), because there will be a $20-50 \%$ chance of prior husband-specific sensitization depending on the number of pregnancies. Indeed, several case reports/series demonstrated that severe early rejection can occur in $\mathrm{H} 2 \mathrm{~W}$ transplantations despite the absence of detectable HLA antibodies prior to transplantation (7-10).

Although $\mathrm{H} 2 \mathrm{~W}$ transplantations carry an unpredictable risk of rejection, some women do not have other options as living donors. In addition, the benefit of a preemptive/timely $\mathrm{H} 2 \mathrm{~W}$ transplantation compared to a yearlong dialysis period and subsequent deceased donor transplantation has to be considered. At our center, we regard $\mathrm{H} 2 \mathrm{~W}$ transplantations as immunological risk and treat these women with $\mathrm{T}$ celldepleting induction. This therapy has been shown to reduce the incidence and severity of rejection in patients with donorspecific HLA antibodies (DSA) (11). So far, outcomes of H2W transplantations receiving $\mathrm{T}$ cell-depleting induction have not been described.

The aim of this study was to investigate pertinent outcomes of $\mathrm{H} 2 \mathrm{~W}$ transplantations treated with $\mathrm{T}$ cell-depleting induction in comparison to other options for women with prior pregnancies receiving their first HLA-mismatched kidney transplant (i.e., other living donor or deceased donor transplantation).

\section{PATIENTS AND METHODS}

\section{Patient Population}

The ethics committee of Northwestern and Central Switzerland approved this retrospective study (www.eknz.ch; project ID 2021-00584). The pregnancy history is documented in all women evaluated for kidney transplantation. In case of spousal donors, we carefully evaluated during the living donor evaluation process, if the spouse was indeed the biological father of the children (i.e., separate interviews of the couple by a physician and a dedicated psychologist).

For this study, we assessed all kidney transplantations in women performed at the University Hospital Basel from January 1st, 2005 until January 31st, 2020 for eligibility $(n=368)$. One-hundred and seventy-one of 368 transplantations (46\%) were excluded for the following reasons: no previous pregnancies $(n=85)$, previous transplantation(s) $(n=56)$, induction protocol violation ( $n=19$; detailed in the immunosuppression section), HLA-identical living donor transplantation $(n=8)$, child-to-mother transplantation $(n=2)$, and unknown pregnancy status $(n=1)$. The remaining 197 women all had their first HLA-mismatched kidney transplantation and previous pregnancies. According to the kidney donor source and the detailed pregnancy history the transplantations were divided into three groups: (i) H2W $(n=25)$, (ii) other living donor $(n=52)$, (iii) deceased donor $(n=120)$.

\section{Living and Deceased Donor Selection Process}

HLA antibody analysis was performed by single antigen beads on the Luminex platform using a cutoff of $500 \mathrm{MFI}$, and DSA were determined by a virtual cross-match approach as previously reported $(5,12)$.

All willing and medically eligible living donors are usually evaluated regarding histocompatibility. Priority is given to donors without DSA constellation. Husbands having mutual children with the recipient were accepted as donors, if no DSA constellation was present. If DSA were present, transplantation was pursued after discussion with the couple regarding other options, and if considered as immunologically feasible (negative $\mathrm{T}$ - and B-cell CDC-cross-matches, and usually no more than three DSA at $\leq 2$ loci and cumulative MFI $<10000$ ). Other living donors with DSA were accepted using the same criteria.

For deceased donor selection, priority is given to DSA negative donors according to the algorithm of the national donor allocation program (13). DSA were accepted in patients with high CPRA, if regarded as immunologically feasible (negative T- and B-cell CDC-crossmatches) (12).

\section{Immunosuppression}

$\mathrm{H} 2 \mathrm{~W}$ transplantations were considered as immunological risk and received an induction therapy consisting of a polyclonal anti $\mathrm{T}$ cell globulin (ATG; Gravalon $9 \mathrm{mg} / \mathrm{kg}$ bw prior to reperfusion of the allograft and $3 \mathrm{mg} / \mathrm{kg}$ bw on day $1-4$ or Thymoglobulin 4 days $1.5 \mathrm{mg} / \mathrm{kg}$ bw). In case of circulating DSA, intravenous immunoglobulins (IvIg) were additionally given (5 days $0.4 \mathrm{~g} / \mathrm{kg}$ bw). Maintenance immunosuppression consisted of tacrolimus (Tac), mycophenolate (MPA) and prednisone. Target tacrolimus trough levels were $10-12 \mathrm{ng} / \mathrm{ml}$ for the first month, $8-10 \mathrm{ng} / \mathrm{ml}$ for months two to three, $6-8 \mathrm{ng} / \mathrm{ml}$ for months four to six, and $4-8 \mathrm{ng} / \mathrm{ml}$ thereafter. Steroids were tapered to $0.1 \mathrm{mg} / \mathrm{kg}$ body weight by month three posttransplant.

For all other transplantations, the induction therapy was selected based on the presence/absence of DSA. Patients without DSA received an induction therapy with basiliximab $(20 \mathrm{mg}$ on day 0 and 4) and triple therapy with Tac-MPA-P or a steroidfree regimen consisting of Tac-MPA and a mTOR-inhibitor. In case of a rejection-free clinical course, immunosuppression was modified and reduced within the first 6 months to establish a dual Tac-MPA therapy on the long-term. Target trough levels of tacrolimus were identical to the levels described above. Patients with DSA received an induction therapy with ATG and IvIg and maintenance immunosuppression consisting of TacMPA-P. Target trough levels of tacrolimus were identical to the levels described above. Steroids were tapered to $0.1 \mathrm{mg} / \mathrm{kg}$ body weight by month three post-transplant and maintained at this level.

All ABO-blood group incompatible (ABOi) transplant recipients received a single dose of rituximab 4 weeks prior to transplantation and immunadsorption depending on the antiblood group titers. 
TABLE 1 | Baseline characteristics.

\begin{tabular}{|c|c|c|c|c|}
\hline Parameter & $\begin{array}{l}\text { Husband-to-wife } \\
\qquad(n=25)\end{array}$ & $\begin{array}{l}\text { Other living donor } \\
\qquad(n=52)\end{array}$ & $\begin{array}{l}\text { Deceased donor } \\
\qquad(n=120)\end{array}$ & $p$ \\
\hline Recipient age & $56(47-64)$ & $49(39-57)$ & $59(53-65)$ & $<0.0001$ \\
\hline ADPKD & $8(32 \%)$ & $16(31 \%)$ & $28(23 \%)$ & 0.48 \\
\hline Diabetic nephropathy & $1(4 \%)$ & $7(13 \%)$ & $13(11 \%)$ & \\
\hline Vascular nephropathy & $2(8 \%)$ & $3(6 \%)$ & $13(11 \%)$ & \\
\hline Other nephropathies & $4(16 \%)$ & $6(12 \%)$ & $8(6 \%)$ & \\
\hline Unknown nephropathy & $4(16 \%)$ & $2(3 \%)$ & $17(14 \%)$ & \\
\hline \multicolumn{5}{|l|}{ Renal replacement therapy } \\
\hline Preemptive transplantation & $12(48 \%)$ & $22(42 \%)$ & $5(4 \%)$ & $<0.0001$ \\
\hline One & $4(16 \%)$ & $23(44 \%)$ & $23(19 \%)$ & 0.004 \\
\hline Two & $13(52 \%)$ & $19(37 \%)$ & $50(42 \%)$ & \\
\hline$\geq 3$ & $8(32 \%)$ & $10(19 \%)$ & 47 (39\%) & \\
\hline Blood transfusions (yes/no/unknown) & $29 \% / 54 \% / 17 \%$ & $24 \% / 69 \% / 8 \%$ & $40 \% / 42 \% / 18 \%$ & 0.03 \\
\hline cPRA (A/B/DR/DQ) [\%] & $1(0-48)$ & $20(0-42)$ & $23(0-78)$ & 0.03 \\
\hline ABO incompatible & $2(8 \%)$ & $10(19 \%)$ & n.a. & n.a. \\
\hline DSA present & $9(36 \%)$ & $8(15 \%)$ & $28(23 \%)$ & 0.13 \\
\hline DSA characteristics & $n=9$ & $n=8$ & $n=28$ & \\
\hline Number & $2(1-3)$ & $2(1,2)$ & $1(1,2)$ & 0.48 \\
\hline Class $(1 / I I / I+I I)$ & $3 / 3 / 3$ & $1 / 3 / 4$ & $10 / 13 / 5$ & 0.40 \\
\hline Cumulative MFI & $1,571(889-7,023)$ & $1,533(1,014-4,269)$ & $1,425(597-4,646)$ & 0.80 \\
\hline ATG \pm Ivlg & $25(100 \%)$ & $8(15 \%)$ & $28(23 \%)$ & $<0.0001$ \\
\hline Basiliximab & - & $44(85 \%)$ & $92(77 \%)$ & \\
\hline \multicolumn{5}{|l|}{ Maintenance immunosuppression } \\
\hline Tac-MPA-P & $25(100 \%)$ & $40(77 \%)$ & $114(95 \%)$ & 0.0007 \\
\hline Tac-MPA-mTOR & - & $11(21 \%)$ & $4(3 \%)$ & \\
\hline Other* & - & $1(2 \%)$ & $2(2 \%)$ & \\
\hline
\end{tabular}

ADPKD, autosomal polycystic kidney disease; DSA, donor-specific HLA-antibodies; ATG, anti T-cell globulin; IVlg, intravenous immunoglobulins; Tac, tacrolimus; MPA, mycophenolic acid; mTOR, mTOR inhibitors; P, prednisone; n.a., not applicable.

${ }^{*}$ No Tac-based immunosuppression.

As mentioned above, 19 transplantations were excluded from the study, because the used induction deviated from the protocol. Most of these violations occurred in deceased donor transplantations due to retrospective DSA status corrections after extending the donor HLA typing (i.e., additional loci or high resolution typing) (14). Only one patient in the $\mathrm{H} 2 \mathrm{~W}$ group was excluded. This patient received an ABOi transplant without DSA and the induction was restricted to rituximab without additional ATG due to her frailty.

\section{Medication as Infection Prophylaxis}

All patients received prophylaxis

with trimethoprim/sulfamethoxazole $(160 / 800 \mathrm{mg}$ three times per week) against pneumocystis jirovecii infection for 6 months. The CMV prevention strategy at our center has been described previously (15). Briefly, high-risk patients $(\mathrm{D}+/ \mathrm{R}-)$ received prophylaxis with oral valganciclovir (Valcyte, Roche) $450 \mathrm{mg}$ twice daily adjusted for renal function. Intermediate-risk patients $(\mathrm{R}+)$ received prophylaxis 
TABLE 2 | Major outcomes.

\begin{tabular}{|c|c|c|c|c|}
\hline Parameter & $\begin{array}{l}\text { Husband-to-wife } \\
\qquad(n=25)\end{array}$ & $\begin{array}{l}\text { Other living donor } \\
\qquad(n=52)\end{array}$ & $\begin{array}{l}\text { Deceased donor } \\
\qquad(n=120)\end{array}$ & $p$ \\
\hline Reason for graft failure & $n=4$ & $n=2$ & $n=5$ & \\
\hline Rejection & 3 & 1 & 2 & n.a. \\
\hline Recurrent GN & 1 & - & - & \\
\hline Vascular/surgical & - & 1 & - & \\
\hline Other & - & - & 3 & \\
\hline Cause of death & $n=0$ & $n=4$ & $n=33$ & \\
\hline Cardiovascular & - & - & 6 & n.a. \\
\hline Malignancy & - & 1 & 5 & \\
\hline Infection & - & 1 & 11 & \\
\hline Other & - & 1 & 4 & \\
\hline Unknown & - & 1 & 7 & \\
\hline \multicolumn{5}{|l|}{ Estimated GFR } \\
\hline At 1 year & 54 (39-68) & $58(47-70)$ & $54(38-70)$ & 0.24 \\
\hline At 3 years & $50(37-62)$ & $61(46-75)$ & $54(32-72)$ & 0.16 \\
\hline At 5 years & $58(38-70)$ & $55(43-75)$ & $51(33-83)$ & 0.60 \\
\hline \multicolumn{5}{|c|}{ Urine protein/creatinine ratio $[\mathrm{mg} / \mathrm{mmol}]$} \\
\hline At 1 year & $10(8-19)$ & $13(8-18)$ & $13(8-24)$ & 0.50 \\
\hline At 3 years & $11(6-22)$ & $11(8-15)$ & $13(9-23)$ & 0.20 \\
\hline At 5 years & $16(8-20)$ & $9(5-23)$ & $13(9-23)$ & 0.25 \\
\hline Post-transplant DSA screening & $n=18$ & $n=34$ & $n=73$ & \\
\hline No de novo DSA & $10(56 \%)$ & $26(76 \%)$ & $44(60 \%)$ & 0.27 \\
\hline De novo DSA & $1(6 \%)$ & $2(6 \%)$ & $10(14 \%)$ & \\
\hline Persisting pre-transplant DSA & $3(16 \%)$ & $1(3 \%)$ & $11(15 \%)$ & \\
\hline Disappearing pre-transplant DSA & $4(22 \%)$ & $5(15 \%)$ & $8(11 \%)$ & \\
\hline
\end{tabular}

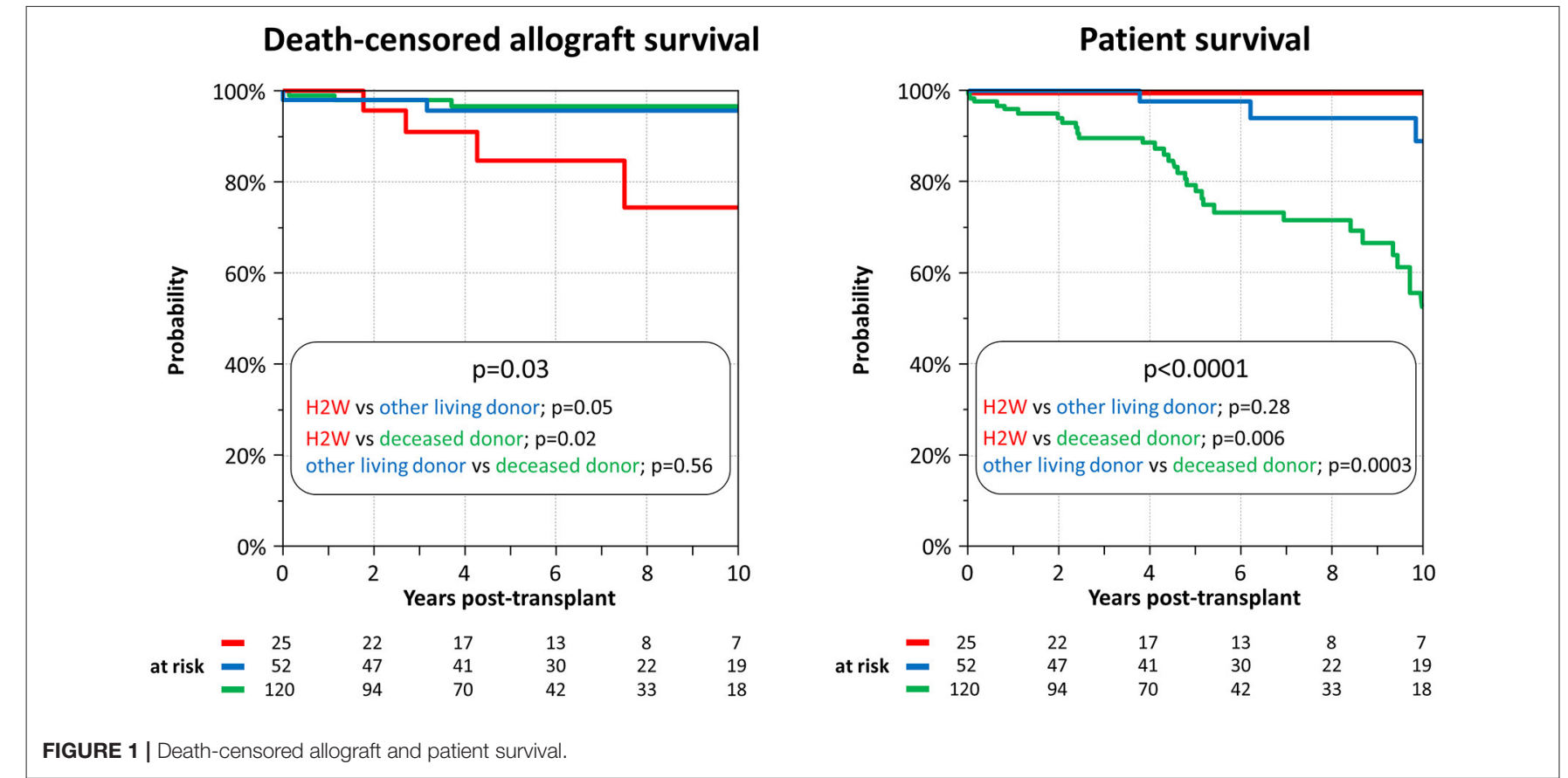

with valganciclovir, if they had an induction therapy with ATG or were ABO-incompatible. All other intermediaterisk patients were managed by regular monitoring and deferred therapy. Low-risk patients (D-/R-) received no prophylaxis and had no regular screening. Prophylaxis was given for a minimum of 3 months and prolonged, if 


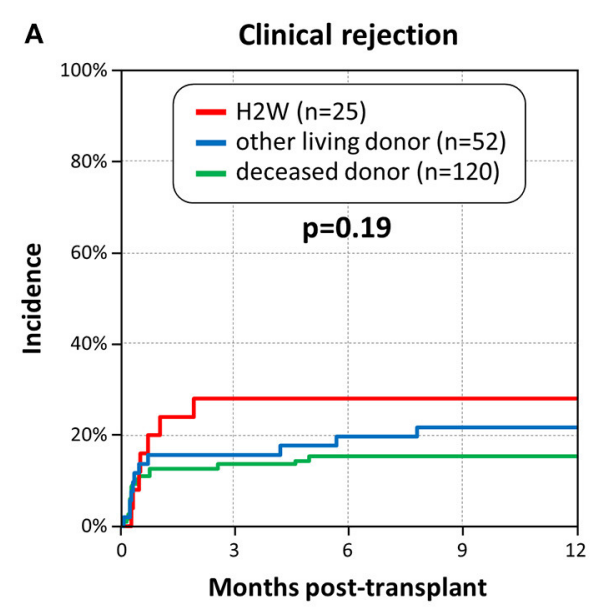

C

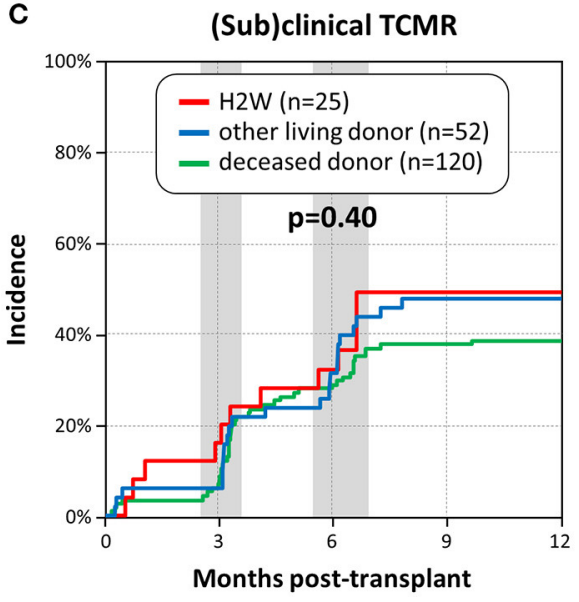

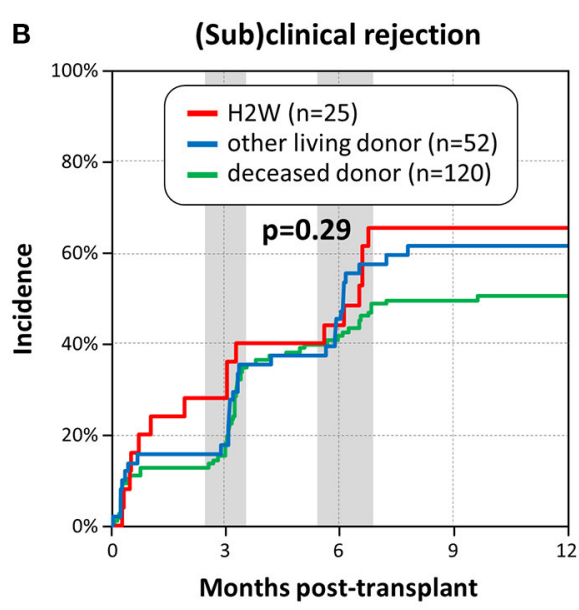

D

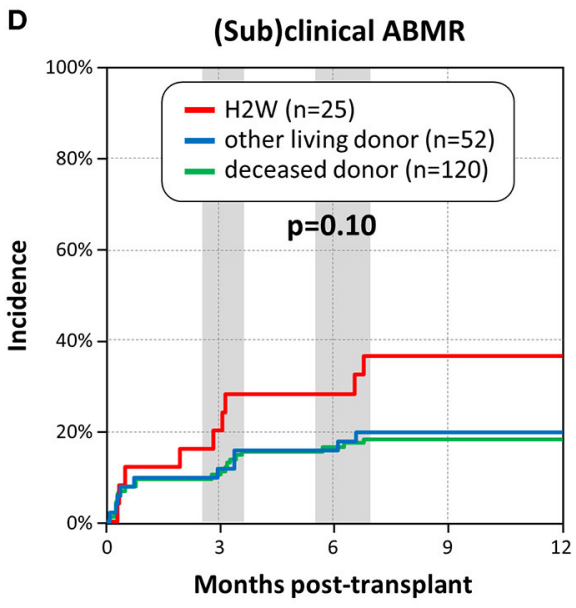

FIGURE 2 | Incidence of rejection within the first year post-transplant. (A) Incidence of clinical rejection. (B) Incidence of (sub)clinical rejection. (C) Incidence of (sub)clinical T cell-mediated rejection (TCMR). (D) Incidence of (sub)clinical antibody-mediated rejection (ABMR), including mixed rejection. The gray background areas represent the two time frames, in which surveillance biopsies at 3 and 6 months were performed.

immunosuppression was still considered as high (e.g., recent rejection therapy).

\section{Assessment and Treatment of Allograft Rejection}

Patients were monitored by surveillance biopsies at 3 and 6 months post-transplant. Clinically indicated allograft biopsies were performed when serum creatinine increased by $>20 \%$ from baseline. Findings were graded according to the Banff 2015 classification (16). Mixed rejection were grouped to antibodymediated rejection (ABMR). Clinical and subclinical rejection episodes were treated according to the phenotype and severity. Clinical T cell-mediated rejection (TCMR) were mainly treated with i.v. steroid pulses (3-5*500 mg methylprednisolone) and a steroid taper. Subclinical TCMR were mainly treated with p.o. steroids $\left(3^{*} 200 \mathrm{mg}\right.$ prednisone) and a steroid taper. Patients with clinical ABMR and mixed rejection episodes received ATG and in some cases in addition IvIg. Subclinical ABMR or mixed rejection were treated with i.v. or p.o. steroid pulses and a steroid taper. Borderline changes, which are by far the most frequent rejection phenotype in the current era of immunosuppression, were regarded and treated as TCMR (17).

\section{Statistical Analysis}

We used JMP software (SAS Institute Inc., Cary, NC) for statistical analysis. Categorical data are presented as counts and/or percentages and were analyzed by chi-square test or Fisher's exact test as appropriate. Continuous data are shown as median and interquartile ranges [IQR] and compared by Wilcoxon rank sum tests. For all tests, a (two-tailed) $p<0.05$ was considered to indicate statistical significance. Time-to-event analyses were performed by the Kaplan-Meier method and compared by the log-rank test. Multivariate Cox regression analysis was used to investigate independent predictors for rejection and graft failure in $\mathrm{H} 2 \mathrm{~W}$ transplantations. 
TABLE 3 | Infections occurring within the first year post-transplant.

\begin{tabular}{|c|c|c|c|c|}
\hline Parameter & $\begin{array}{l}\text { Husband-to-wife } \\
\qquad(n=25)\end{array}$ & $\begin{array}{l}\text { Other living donor } \\
\qquad(n=52)\end{array}$ & $\begin{array}{l}\text { Deceased donor } \\
\qquad(n=120)\end{array}$ & $p$ \\
\hline \multicolumn{5}{|l|}{ Polyomavirus BK } \\
\hline No relevant viruria (i.e., no Decoy cells) & 18 (72\%) & $34(65 \%)$ & $86(72 \%)$ & 0.29 \\
\hline Viruria, but no viremia & $6(24 \%)$ & $13(25 \%)$ & $15(13 \%)$ & \\
\hline Viremia & $1(4 \%)$ & $4(8 \%)$ & $17(14 \%)$ & \\
\hline Definitive BK-nephropathy & - & $1(2 \%)$ & $2(2 \%)$ & \\
\hline \multicolumn{5}{|l|}{ CMV } \\
\hline No CMV viremia & $21(84 \%)$ & $43(83 \%)$ & $73(61 \%)$ & 0.01 \\
\hline Asymptomatic CMV viremia & $3(12 \%)$ & $9(17 \%)$ & $27(22 \%)$ & \\
\hline CMV syndrome & - & - & $12(10 \%)$ & \\
\hline Tissue-invasive CMV disease & $1(4 \%)$ & - & $8(7 \%)$ & \\
\hline \multicolumn{5}{|l|}{ Other infections including lower UTI } \\
\hline None & $8(32 \%)$ & 18 (35\%) & $31(26 \%)$ & 0.24 \\
\hline Only one & $6(24 \%)$ & $19(37 \%)$ & 32 (27\%) & \\
\hline$\geq 2$ infections & $11(44 \%)$ & $15(29 \%)$ & $57(47 \%)$ & \\
\hline \multicolumn{5}{|l|}{ Other infections excluding lower UTI } \\
\hline None & 13 (52\%) & $29(56 \%)$ & $66(55 \%)$ & 0.22 \\
\hline Only one & $5(20 \%)$ & $18(34 \%)$ & $29(24 \%)$ & \\
\hline$\geq 2$ infections & $7(28 \%)$ & $5(10 \%)$ & $25(21 \%)$ & \\
\hline
\end{tabular}

UTI, urinary tract infection.

\section{RESULTS}

\section{Baseline Characteristics}

Baseline characteristics of the three groups are summarized in Table 1. We observed significant differences regarding several parameters. Recipients in the deceased donor and $\mathrm{H} 2 \mathrm{~W}$ groups were older than in the other living donor group ( 59 vs. 56 vs. 49 years; $p<0.0001$ ). In addition, women in the $\mathrm{H} 2 \mathrm{~W}$ and deceased donor groups had more often $\geq 2$ pregnancies compared to the other living donor group. As expected, the latter group had less HLA mismatches than the other groups due to related infamily donors (i.e., parents, siblings). We observed no statistically significant differences regarding the frequency of DSA as well as their characteristics. CMV constellations were equally distributed among the three groups, but prophylaxis with valganciclovir was given more often in the $\mathrm{H} 2 \mathrm{~W}$ group due to universal use of ATG induction. Maintenance immunosuppression with Tac and MPA was used in 194/197 patients (98\%).

\section{Patient and Graft Survival}

After a median follow-up time of 5.1 years (IQR 2.9-9.0), 11/197 allograft (5.6\%) failed: four in the $\mathrm{H} 2 \mathrm{~W}$ group, two in the other living donor group, and five in the deceased donor group. Rejection accounted for $6 / 11$ graft failures (55\%), three of these occurred in the $\mathrm{H} 2 \mathrm{~W}$ group. One of these three patients had DSA (Cw4 and DR15 with cumulative MFI of 5759), the other two patients had no DSA. Details on the reasons for graft loss are summarized in Table 2. Death-censored allograft survival was significantly lower in the $\mathrm{H} 2 \mathrm{~W}$ group compared to the other two groups $(p=0.03)$. In detail, 1-year survival was still similar among the three groups (100 vs. 98 vs. $99 \%$ ), but lower in the
H2W group at five ( 85 vs. 96 vs. $97 \%$ ) and 10 years ( 74 vs. 96 vs. 97\%) (Figure 1).

Thirty-seven of 197 patients (19\%) died. None in the H2W group, 4 in the other living donor group and 33 in the deceased donor group. Leading causes of death were infections $(n=12)$, cardiovascular diseases $(n=6)$, and malignancies $(n=6)$ (Table 2). Patient survival was significantly lower in the deceased donor group compared to the other two groups $(p<0.0001)$ (Figure 1). Notable, patient survival was similar in the $\mathrm{H} 2 \mathrm{~W}$ and the other living donor group $(p=0.28)$.

The median estimated glomerular filtration rate (eGFR) and proteinuria of functioning allograft were similar among the three groups at one, three and 5 years post-transplant (Table 2).

\section{Allograft Rejection}

Overall, the 197 patients had 81 clinical biopsies within the first year as well as 259 surveillance biopsies at 3 and 6 months, respectively. Only 37/197 patients (19\%) had no allograft biopsy at all within the first year post-transplant. The frequency of clinical and surveillance biopsies was not different among the three groups ( $p=0.20$ and $p=0.38$ ). Clinical biopsies beyond the first year post-transplant were obtained in 34/197 patients (17\%), with similar frequency among the three groups $(p=0.64)$.

The 1-year incidence of clinical rejection was statistically not different among the three groups $(p=0.19)$, but numerically highest in the $\mathrm{H} 2 \mathrm{~W}$ group (28 vs. 22 vs. $15 \%$ ). We observed similar incidences of (sub)clinical rejection and (sub)clinical TCMR $(p=0.29$ and $p=0.40)$ among the three groups. Interestingly, the incidence of (sub)clinical ABMR was numerically around twice as high in the $\mathrm{H} 2 \mathrm{~W}$ group compared 
to the other groups ( 36 vs. 20 vs. $18 \%$ ), but this did not reach statistical significance $(p=0.10)$ (Figure 2).

\section{Infections Within the First Year}

Infections occurring within the first year post-transplant are summarized in Table 3. We observed no differences regarding frequency and severity of polyomavirus BK infection (BKV). Cytomegalovirus (CMV) infections were more frequent and more severe in the deceased donor group compared to the other groups $(p=0.01)$. However, they were equally often observed in the $\mathrm{H} 2 \mathrm{~W}$ and the other living donor group.

We recorded 345 infections other than BKV and CMV. The percentage of patients having no, one or $\geq 2$ infections was not different among the three groups $(p=0.24)$. As expected, lower urinary tract infections (UTI) were the most frequent infection accounting for $54 \%$ of all cases, followed by upper airway infections (13\%), gastrointestinal infections (11\%), skin infections (9\%), and upper UTI (i.e., pyelonephritis) with $7 \%$. Fungal infections were rare $(15 / 345 ; 4.3 \%)$. When excluding lower UTI, about $50 \%$ patients in the three groups experienced no infection within the first year post-transplant (Table 3).

\section{Evolution of Pre-transplant DSA and Development of de novo DSA}

Post-transplant screening for HLA antibodies was performed in $125 / 197$ patients $(63 \%)$, including $35 / 45$ women having pretransplant DSA (78\%) and 90/152 women without pre-transplant DSA (59\%). The frequency of screening was similar among the three groups (H2W $72 \%$, other living donor 65\%, deceased donor $61 \% ; p=0.54$ ) and was performed at median of 3.1 years posttransplant. Of 35 patients with pre-transplant DSA, 3 developed de novo DSA (9\%), 15 had persisting DSA (43\%), and in 17 cases DSA disappeared (48\%). In those 90 women without pretransplant DSA, 10 developed de novo DSA (11\%). The frequency of de novo DSA, persisting or disappearing DSA was not different among the three groups $(p=0.27)$ (Table 2).

\section{Predictors of Rejection and Graft Failure in H2W Transplantations}

During the whole follow-up 16/25 H2W transplantations developed (sub)clinical rejection, 10/25 clinical rejection, and $4 / 25$ allograft failed. DSA status (yes/no), number of pregnancies ( 1 vs. $\geq 2$ ), and HLA-mismatches were not associated with any of the above mentioned events in univariate analysis and multivariate Cox-models (all $p \geq 0.09$ ).

\section{Review of the Literature}

We found 10 publications investigating $\mathrm{H} 2 \mathrm{~W}$ transplantations with prior pregnancies: 5 cohort studies, 4 detailed case reports, and one case series (Table 4).

Nine of ten reports were published between 1995 and 2008. In these studies, a Tac- or cyclosporine-based immunosuppression without induction therapy was used for most patients. All patients were considered as having no pre-transplant DSA by either cytotoxicity or flowcytometric crossmatches. The five cohort studies or case series published between 1995 and 2008 reported 1-year graft survival from 60 to $90 \%$, which was mostly lower than in the comparison groups and lower than in our study $(100 \%)(10,19-22)$. All case reports described acute antibodymediated or mixed rejection episodes within the first week posttransplant, which could be successfully reversed $(7-9,23)$.

The only more recent publication in 2020 by Kim et al. reported on $159 \mathrm{H} 2 \mathrm{~W}$ transplantations using Tac-MPA-P immunosuppression and basiliximab induction (18). They observed a higher frequency of clinical rejection in the $\mathrm{H} 2 \mathrm{~W}$ group, but similar patient and graft survival compared to offspring-to-mother and other living unrelated donors.

\section{DISCUSSION}

The key observation is this study was that despite $\mathrm{T}$ celldepleting induction, H2W transplantations have a higher risk for death-censored graft loss possibly mediated by a higher frequency of ABMR compared to other HLAmismatched living or deceased donor transplantations in women with prior pregnancies. However, patient survival in H2W transplantation is excellent, and the universal use of $\mathrm{T}$ cell-depleting induction was not associated with a higher frequency or infections within the first year post-transplant.

Previous cohort studies published between 1995 and 2008 reported 1-year graft survival rates between 78 and $90 \%$ in $\mathrm{H} 2 \mathrm{~W}$ transplantations, which were mostly lower than in the comparison groups (19-22). Although the frequency of rejection was often not reported, we assume that most of these $10-20 \%$ early graft losses might be related to rejection, which were not prevented by the used immunosuppressive protocol. We speculate that ATG induction together with TacMPA-P maintenance immunosuppression contributed to the better 1-year graft survival (i.e., 100\%) in our study. Support for this interpretation comes from a retrospective cohort study, which demonstrates the efficacy of ATG induction in allograft recipients with pre-existing donor-specific sensitization (11). Clearly, only a prospective randomized study in $\mathrm{H} 2 \mathrm{~W}$ transplantations comparing ATG vs. other induction (e.g., basiliximab) or no induction can provide more conclusive evidence, but it is very unlikely that such a study will ever be performed.

A recent study from South Korea reported excellent short and long-term graft survival in $159 \mathrm{H} 2 \mathrm{~W}$ transplantations receiving basiliximab induction and Tac-MPA-P maintenance immunosuppression (18). We cannot explain these favorable results compared to reports from Europe and North America. One possibility might be that South Korea has a less heterogeneous population and hence less immunogenic HLA mismatches. Furthermore, the number of pregnancies was not reported in their study. A lower frequency of prior pregnancies will reduce the overall risk of a husbandspecific sensitization, which can critically influence the outcome (1).

Our study as well as most of the referenced publications highlight that $\mathrm{H} 2 \mathrm{~W}$ transplantations are associated with a wide range of outcomes, ranging from early, severe rejection 
TABLE 4 | Review of the literature.

\begin{tabular}{|c|c|c|c|c|c|c|c|c|c|c|c|}
\hline References & Study type & H2W (n) & $\begin{array}{l}\text { Number of } \\
\text { pregnancies }\end{array}$ & $\begin{array}{l}\text { Husband as } \\
\text { biological } \\
\text { father } \\
\text { confirmed }\end{array}$ & $\begin{array}{l}\text { Pre- } \\
\text { transplant } \\
\text { DSA } \\
\text { assessed }\end{array}$ & $\begin{array}{l}\text { With } \\
\text { DSA }\end{array}$ & Induction & $\begin{array}{l}\text { Maintenance } \\
\text { immuno- } \\
\text { suppression }\end{array}$ & $\begin{array}{l}\text { Patient } \\
\text { survival }\end{array}$ & $\begin{array}{l}\text { Graft } \\
\text { survival }\end{array}$ & Key observation \\
\hline $\begin{array}{l}\text { This } \\
\text { manuscript }\end{array}$ & Cohort study & 25 & $\begin{array}{l}1 \text { preg: } 16 \% \\
2 \text { preg: } 52 \% \\
\geq 3 \text { preg: } 32 \%\end{array}$ & Yes & $\begin{array}{l}\text { Yes (Luminex } \\
\text { SA) }\end{array}$ & $36 \%$ & ATG \pm Ivlg & Tac-MPA-P & $\begin{array}{l}1 \text { year: } 100 \% \\
5 \text { years: } 100 \%\end{array}$ & $\begin{array}{l}1 \text { year: } 100 \% \\
5 \text { years: } 85 \%\end{array}$ & $\begin{array}{l}\text { Death-censored graft } \\
\text { survival lower in } \mathrm{H} 2 \mathrm{~W} \\
\text { compared with other } \\
\text { living or deceased } \\
\text { donors }\end{array}$ \\
\hline Kim et al. (18) & Cohort study & 159 & $\begin{array}{l}\text { At least one } \\
\text { (no details } \\
\text { given) }\end{array}$ & No & $\begin{array}{l}\text { Yes (method } \\
\text { not reported; } \\
\text { likely } \\
\text { solid-phase } \\
\text { assays) }\end{array}$ & $32 \%$ & $\begin{array}{l}\text { ATG (4\%) } \\
\text { Basiliximab } \\
\text { (96\%) }\end{array}$ & $\begin{array}{l}\text { Tac-MPA-P } \\
(79 \%)\end{array}$ & 5 years: $98 \%$ & 5 years: $96 \%$ & $\begin{array}{l}\text { No difference in patient } \\
\text { and graft survival } \\
\text { compared with } \\
\text { offspring-to-mother } \\
\text { ( } n=175) \text { and other } \\
\text { living unrelated donors } \\
(n=56) \text {, but higher } \\
\text { rate of clinical rejection }\end{array}$ \\
\hline $\begin{array}{l}\text { Ghafari et al. } \\
\text { (19) }\end{array}$ & Cohort study & 9 & $\begin{array}{l}2-5 \text { (mean } \\
2.6)\end{array}$ & No & $\begin{array}{l}\text { Yes (AHG- } \\
\text { CDC-XM) }\end{array}$ & $0 \%$ & None & $\begin{array}{l}\text { CyA- } \\
\text { MPA/AZA-P }\end{array}$ & $\begin{array}{l}1 \text { year: } 97 \% \\
5 \text { years: } 78 \%\end{array}$ & $\begin{array}{l}1 \text { year: } 78 \% \\
5 \text { years: } 69 \%\end{array}$ & $\begin{array}{l}\text { More rejection and } \\
\text { lower graft survival } \\
\text { compared to other } \\
\text { living unrelated donors }\end{array}$ \\
\hline $\begin{array}{l}\text { Pretagostini } \\
\text { et al. }(20)^{\star}\end{array}$ & Cohort study & 33 & $\begin{array}{l}\text { At least one } \\
\text { (no details } \\
\text { given) }\end{array}$ & No & $\begin{array}{l}\text { Yes } \\
\text { (CDC-XM) }\end{array}$ & $0 \%$ & Not reported & CyA-based & Not reported & $\begin{array}{l}1 \text { year: } 80 \% \\
5 \text { years: } 73 \%\end{array}$ & $\begin{array}{l}\text { Lower } 1 \text { year graft } \\
\text { survival compared to } \\
\text { W2H (90\%) and other } \\
\text { unrelated living donor } \\
(100 \%)\end{array}$ \\
\hline $\begin{array}{l}\text { Gjertson et al. } \\
\text { (21) }\end{array}$ & Cohort study & 407 & $\begin{array}{l}1 \text { preg: } 31 \% \\
\geq 2 \text { preg: } 69 \%\end{array}$ & No & $\begin{array}{l}\text { Yes } \\
\text { (CDC-XM) }\end{array}$ & $0 \%$ & Not reported & Not reported & Not reported & $\begin{array}{l}1 \text { year: } 90 \% \\
5 \text { years: } 78 \%\end{array}$ & $\begin{array}{l}\text { No difference in graft } \\
\text { survival according to } \\
\text { the number of } \\
\text { pregnancies in } \mathrm{H} 2 \mathrm{~W}\end{array}$ \\
\hline $\begin{array}{l}\text { Terasaki et al. } \\
\text { (22) }\end{array}$ & Cohort study & 75 & $\begin{array}{l}\text { At least one } \\
\text { (no details } \\
\text { given) }\end{array}$ & No & $\begin{array}{l}\text { Not reported } \\
\text { (likely } \\
\text { CDC-XM) }\end{array}$ & n.a. & Not reported & Not reported & Not reported & $\begin{array}{l}1 \text { year: } 87 \% \\
3 \text { years: } 76 \%\end{array}$ & $\begin{array}{l}\text { Graft survival @3 years } \\
\text { worse compared to } \\
\text { H2W without any } \\
\text { pregnancies ( } 76 \% \text { vs. } \\
87 \% ; p=0.40 \text { ) }\end{array}$ \\
\hline $\begin{array}{l}\text { Ortiz-Arroyo } \\
\text { et al. (10) }\end{array}$ & Case series & 5 & $\begin{array}{l}\text { At least one } \\
\text { (no details } \\
\text { given) }\end{array}$ & No & $\begin{array}{l}\text { Yes (AHG- } \\
\text { CDC-XM) }\end{array}$ & $0 \%$ & $\begin{array}{l}\text { Basiliximab } \\
(40 \%)\end{array}$ & Triple therapy & Not reported & 1 year: 60\% & $\begin{array}{l}\text { Two out of five patients } \\
\text { developed acute ABMR } \\
\text { and lost the graft }\end{array}$ \\
\hline $\begin{array}{l}\text { Matsuo et al. } \\
\text { (9) }\end{array}$ & Case report & 1 & 2 & Yes & $\begin{array}{l}\text { Yes } \\
\text { (FCXM/FlowPRA) }\end{array}$ & No & Basiliximab & Tac-MPA-P & \multicolumn{2}{|c|}{ Good function at $6 \mathrm{mt}$} & $\begin{array}{l}\text { Acute ABMR starting } \\
\text { POD 3, reversed by } \\
\text { plasmapheresis, } \\
\text { steroids and rituximab }\end{array}$ \\
\hline
\end{tabular}




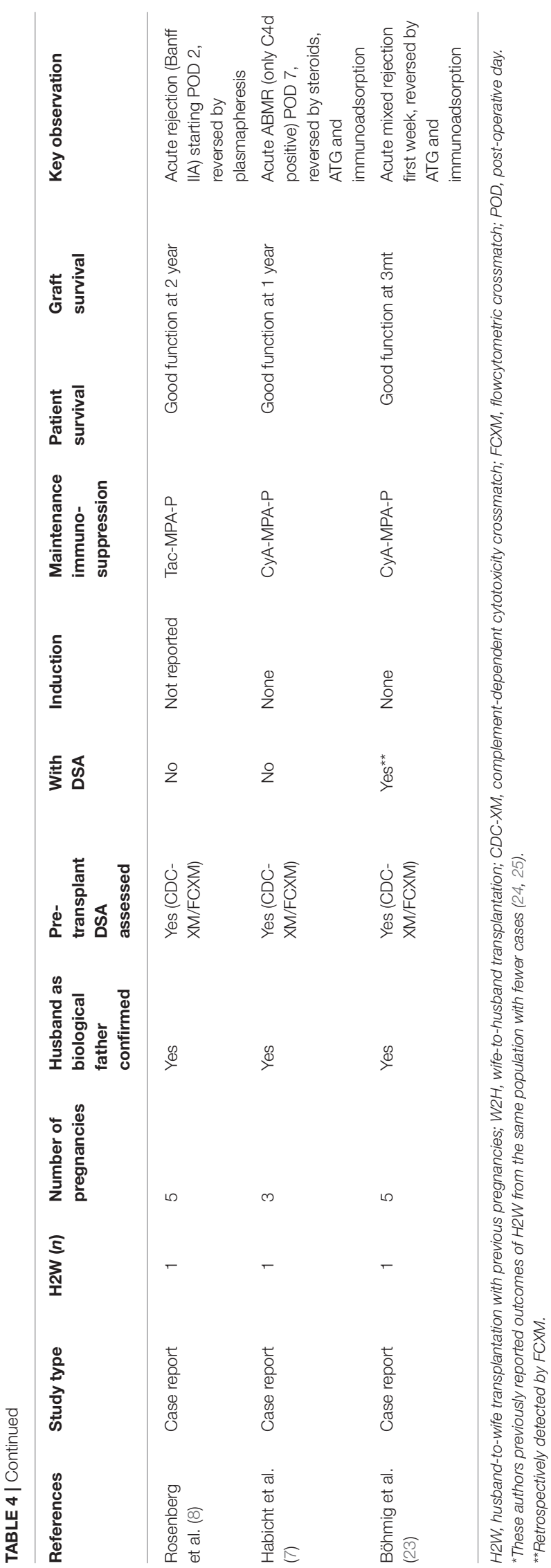

and graft loss to uneventful courses. Unfortunately, currently available parameters such as presence of DSA, number of pregnancies, and number of HLA mismatches seem not to be very predictive. Analyses on the molecular level of HLA disparities (i.e., eplet load and eplet immunogenicity) might provide better prediction, but such an evaluation would require a significantly larger number of cases (26-30). Another interesting approach could be the evaluation of memory B cell responses (31). With recent advances to detect memory B cells, it seems nowadays possible to obtain a more complete picture of the pre-transplant alloimmunization status in these women (32-35). Since the magnitude of memory B cell responses following previous HLA immunization such as pregnancies may differ, their detection might explain the higher proportion of early (sub)clinical rejection episodes in $\mathrm{H} 2 \mathrm{~W}$ transplants, as observed in our study and described before (710, 23).

How should we council pairs in evaluation for a $\mathrm{H} 2 \mathrm{~W}$ transplantation? If the husband is indeed the biological father of the mutual child/children, we recommend to use an appropriate immunosuppressive regimen including ATG induction and to discuss with the pair the increased risk for rejection as well as allograft failure. Alternative living donors having different HLA haplotypes than the biological father should be prioritized, especially in case of numerous pregnancies. If a broad and/or high husband-specific sensitization can be detected by single antigen bead assays and no alternative suitable living donor is available, a deceased donor transplantation or inclusion in a kidney-paired donation program avoiding all major DSA might be the best option (36). Avoidance of even all mismatched husband HLA antigens (despite lack of detectable husbandspecific sensitization by the most sensitive techniques) by opting for deceased donor transplantation is probably the safest approach to prevent early severe rejection (37). However, this will often significantly reduce the pool of suitable donors. From a statistical point of view, a woman with two full-term pregnancies has a $40 \%$ risk to be sensitized against any HLA$\mathrm{A} / \mathrm{B} / \mathrm{C} / \mathrm{DRB} 1$ mismatches of the father (1). If a deceased donor shares only one HLA mismatch with the father, the risk of performing the transplantation in the presence of pre-existing sensitization will be much lower in most cases, but it still exists (37).

Despite a numerically higher incidence of $A B M R$ in the $\mathrm{H} 2 \mathrm{~W}$ group compared to the other two groups, the frequency of detectable circulating DSA post-transplant was not different. Notably, post-transplant screening for DSA was not performed at the time of allograft biopsies, but mainly beyond the first year post-transplant after a median of 3.1 years. It is possible that the frequency of circulating DSA post-transplant is underestimated due to absorbance of circulating DSA in the allograft.

Patient survival in the deceased donor group was rather low, but death-censored allograft survival excellent (Figure 1). Notably, the women in this group were significantly older (median 59 years) and had longer dialysis vintage time (median 2.6 years) compared to the other groups. Therefore, they had very likely more relevant comorbidities and a poorer health condition, which were 
responsible for the high mortality. Patient death is the leading cause of allograft loss in elderly patients, which will consequentially lead to a high death-censored allograft survival (38).

This study has certain limitations. First, as in all previous reports, $\mathrm{H} 2 \mathrm{~W}$ transplantations represent a real-life selection, and it is difficult to define appropriate control groups. To reduce biases, we decided to include all women with prior pregnancies, who received the first HLA-mismatched kidney transplant and grouped them according to the donor source. The defined groups (H2W, other living donor, and deceased donor) essentially delineate the three possible options for women with prior pregnancies. Second, several analyses have clear statistical limitations due to a low patient number in the $\mathrm{H} 2 \mathrm{~W}$ group $(n=25)$ and/or low event rates. In particular, the absence of significant predictors of rejection and allograft failure in $\mathrm{H} 2 \mathrm{~W}$ transplantations has to be interpreted with caution. Third, review of the literature revealed that important parameters such as number of pregnancies, definition and presence of DSA, and induction therapy are incompletely reported, making comparison between studies difficult.

In conclusion, $\mathrm{H} 2 \mathrm{~W}$ transplantation with mutual children is a valuable option, but is associated with a higher risk of allograft loss due to rejection despite $\mathrm{T}$ cell-depleting induction. Further research is required to better predict this risk on an individual patient level.

\section{REFERENCES}

1. Honger G, Fornaro I, Granado C, Tiercy JM, Hosli I, Schaub S. Frequency and determinants of pregnancy-induced child-specific sensitization. Am J Transplant. (2013) 13:746-53. doi: 10.1111/ajt.12048

2. Triulzi DJ, Kleinman S, Kakaiya RM, Busch MP, Norris PJ, Steele WR, et al. The effect of previous pregnancy and transfusion on HLA alloimmunization in blood donors: implications for a transfusionrelated acute lung injury risk reduction strategy. Transfusion. (2009) 49:1825-35. doi: 10.1111/j.1537-2995.2009.02206.x

3. Middelburg RA, Porcelijn L, Lardy N, Briet E, Vrielink H. Prevalence of leucocyte antibodies in the Dutch donor population. Vox Sang. (2011) 100:327-35. doi: 10.1111/j.1423-0410.2010.01420.x

4. van Kampen CA, Langerak-Langerak J, Roelen DL, Claas FH. Kinetics of the pregnancy-induced humoral and cellular immune response against the paternal HLA class I antigens of the child. Hum Immunol. (2002) 63:4528. doi: 10.1016/S0198-8859(02)00396-8

5. Wehmeier C, Honger G, Cun H, Amico P, Hirt-Minkowski P, Georgalis A, et al. Donor specificity but not broadness of sensitization is associated with antibody-mediated rejection and graft loss in renal Allograft recipients. Am J Transplant. (2017) 17:2092-102. doi: 10.1111/ajt.14247

6. Gatault P, Jollet I, Rabot N, Boulanger MD, Taupin JL, Barbet C, et al. Mothers without HLA antibodies before transplantation have a low risk of alloimmunization post-transplantation. Tissue Antigens. (2011) 78:2418. doi: 10.1111/j.1399-0039.2011.01757.x

7. Habicht A, Regele H, Exner M, Soleiman A, Horl WH, Watschinger B, et al. A case of severe C4d-positive kidney allograft dysfunction in the absence of histomorphologic features of rejection. Wien Klin Wochenschr. (2002) 114:945-8.

8. Rosenberg JC, Jones B, Oh H. Accelerated rejection following offspring-tomother and husband-to-wife transplants. Clin Transplant. (2004) 18:72933. doi: 10.1111/j.1399-0012.2004.00250.x

9. Matsuo N, Yamamoto H, Kobayashi A, Yamamoto I, Mitome J, Maruyama $\mathrm{Y}$, et al. A case of accelerated acute rejection after ABO-compatible living

\section{DATA AVAILABILITY STATEMENT}

The raw data supporting the conclusions of this article will be made available by the authors, without undue reservation.

\section{ETHICS STATEMENT}

The studies involving human participants were reviewed and approved by Ethics committee of Northwestern and Central Switzerland (www.eknz.ch); project ID 2021-00584. Written informed consent for participation was not required for this study in accordance with the national legislation and the institutional requirements.

\section{AUTHOR CONTRIBUTIONS}

LS and SS: designed study, performed research, analyzed data, and wrote the manuscript. LS, CW, GH, PA, PH-M, and IG: collected data. CW, GH, IG, PA, PH-M, JS, and MD: critically reviewed and revised the manuscript. All authors contributed to the article and approved the submitted version.

\section{ACKNOWLEDGMENTS}

We thank the nurses in the outpatient clinic for their outstanding help in the management of the patients.

unrelated kidney transplantation. Clin Transplant. (2009) 23(Suppl 20):236. doi: 10.1111/j.1399-0012.2009.01004.x

10. Ortiz-Arroyo VM, Granados J, Uribe-Uribe N, de Leo C, Castelan N, Gonzalez $\mathrm{N}$, et al. [Husband to wife kidney transplantation in five multiparous women: sensitization or tolerance after pregnancy?]. Rev Invest Clin. (2004) 56:427-36.

11. Bachler K, Amico P, Honger G, Bielmann D, Hopfer H, Mihatsch MJ, et al. Efficacy of induction therapy with ATG and intravenous immunoglobulins in patients with low-level donor-specific HLA-antibodies. Am J Transplant. (2010) 10:1254-62. doi: 10.1111/j.1600-6143.2010.03093.x

12. Amico P, Hirt-Minkowski P, Honger G, Gurke L, Mihatsch MJ, Steiger J, et al. Risk stratification by the virtual crossmatch: a prospective study in 233 renal transplantations. Transpl Int. (2011) 24:560-9. doi: 10.1111/j.1432-2277.2011.01235.x

13. Schaub S, Immer F, Steiger J. Organ Transplantation in Switzerland. Transplantation. (2019) 103:853-6. doi: 10.1097/TP.0000000000002565

14. Senev A, Emonds MP, Van Sandt V, Lerut E, Coemans M, Sprangers B, et al. Clinical importance of extended second field high-resolution HLA genotyping for kidney transplantation. Am J Transplant. (2020) 20:336778. doi: 10.1111/ajt.15938

15. Bischof N, Wehmeier C, Dickenmann M, Hirt-Minkowski P, Amico P, Steiger $\mathrm{J}$, et al. Revisiting cytomegalovirus serostatus and replication as risk factors for inferior long-term outcomes in the current era of renal transplantation. Nephrol Dial Transplant. (2020) 35:346-56. doi: 10.1093/ndt/gfz268

16. Loupy A, Haas M, Solez K, Racusen L, Glotz D, Seron D, et al. The Banff 2015 kidney meeting report: current challenges in rejection classification and prospects for adopting molecular pathology. Am J Transplant. (2017) 17:28-41. doi: 10.1111/ajt.14107

17. Wehmeier C, Amico P, Hirt-Minkowski P, Georgalis A, Hoenger G, Menter $\mathrm{T}$, et al. Acute rejection phenotypes in the current era of immunosuppression: a single-center analysis. Transplant Direct. (2017) 3:e136. doi: 10.1097/TXD.0000000000000650

18. Kim JY, Choi MC, Kim DH, Ko Y, Lim SJ, Jung JH, et al. Outcomes of living-donor kidney transplantation in female recipients with possible pregnancy-related pre-sensitization according to donor 
relationship. Ann Transplant. (2020) 25:e925229. doi: 10.12659/AOT. 925229

19. Ghafari A. Offspring-to-mother and husband-to-wife renal transplantation: a single-center experience. Transplant Proc. (2008) 40:140-2. doi: 10.1016/j.transproceed.2007.11.062

20. Pretagostini R, Rossi M, Iappelli M, Poli L, Bruzzone P, Casciaro GE, et al. Survival in kidney transplantation from living donors: a single-center experience. Transplant Proc. (2004) 36:467-9. doi: 10.1016/j.transproceed.2004.02.002

21. Gjertson DW, Cecka JM. Living unrelated donor kidney transplantation. Kidney Int. (2000) 58:491-9. doi: 10.1046/j.1523-1755.2000.00195.x

22. Terasaki PI, Cecka JM, Gjertson DW, Takemoto S. High survival rates of kidney transplants from spousal and living unrelated donors. $N$ Engl J Med. (1995) 333:333-6. doi: 10.1056/NEJM199508103330601

23. Bohmig GA, Regele H, Saemann MD, Exner M, Druml W, Kovarik J, et al. Role of humoral immune reactions as target for antirejection therapy in recipients of a spousal-donor kidney graft. Am J Kidney Dis. (2000) 35:66773. doi: 10.1016/S0272-6386(00)70014-X

24. Poli L, Pretagostini R, Rossi M, Novelli G, Berloco P, Iappelli M, et al. Effect of HLA compatibility, pregnancies, blood transfusions, and taboo mismatches in living unrelated kidney transplantation. Transplant Proc. (2001) 33(1-2):1136-8. doi: 10.1016/S0041-1345(00)02 805-0

25. Alfani D, Pretagostini R, Rossi M, Poli L, Bruzzone P, Colonnello M, et al. Living unrelated kidney transplantation: a 12-year single center experience. Transplant Proc. (1997) 29:191-4. doi: 10.1016/S0041-1345(96)00059-0

26. Wiebe C, Kosmoliaptsis V, Pochinco D, Taylor CJ, Nickerson P. A Comparison of HLA molecular mismatch methods to determine HLA immunogenicity. Transplantation. (2018) 102:1338-43. doi: 10.1097/TP.0000000000002117

27. Wiebe C, Nickerson PW. Human leukocyte antigen molecular mismatch to risk stratify kidney transplant recipients. Curr Opin Organ Transplant. (2020) 25:8-14. doi: 10.1097/MOT.0000000000000714

28. Wiebe C, Rush DN, Gibson IW, Pochinco D, Birk PE, Goldberg A, et al. Evidence for the alloimmune basis and prognostic significance of Borderline T cell-mediated rejection. Am J Transplant. (2020) 20:2499508. doi: 10.1111/ajt.15860

29. Honger G, Niemann M, Schawalder L, Jones J, van Heck MR, van de Pasch LAL, et al. Toward defining the immunogenicity of HLA epitopes: impact of HLA class I eplets on antibody formation during pregnancy. HLA. (2020) 96:589-600. doi: 10.1111/tan.14054

30. Schawalder L, Honger G, Kleiser M, van Heck MR, van de Pasch LAL, Vendelbosch S, et al. Development of an immunogenicity score for HLA-DQ eplets: a conceptual study. HLA. (2021) 97:30-43. doi: 10.1111/tan.14110

31. Wehmeier C, Karahan GE, Heidt S. HLA-specific memory Bcell detection in kidney transplantation: insights and future challenges. Int J Immunogenet. (2020) 47:227-34. doi: 10.1111/iji. 12493
32. Karahan GE, de Vaal YJH, Krop J, Wehmeier C, Roelen DL, Claas FHJ, et al. A memory B cell crossmatch assay for quantification of donor-specific memory B cells in the peripheral blood of HLA-immunized individuals. Am J Transplant. (2017) 17:2617-26. doi: 10.1111/ajt.14293

33. Karahan GE, Krop J, Wehmeier C, de Vaal YJH, Langerak-Langerak J, Roelen DL, et al. An easy and sensitive method to profile the antibody specificities of HLA-specific memory B cells. Transplantation. (2019) 103:71623. doi: 10.1097/TP.0000000000002516

34. Wehmeier C, Karahan GE, Krop J, de Vaal Y, Langerak-Langerak J, Binet I, et al. Donor-specific B cell memory in alloimmunized kidney transplant recipients: first clinical application of a novel method. Transplantation. (2020) 104:1026-32. doi: 10.1097/TP.0000000000002909

35. Luque S, Lucia M, Melilli E, Lefaucheur C, Crespo M, Loupy A, et al. Value of monitoring circulating donor-reactive memory B cells to characterize antibody-mediated rejection after kidney transplantation. Am J Transplant. (2019) 19:368-80. doi: 10.1111/ajt.15055

36. Bromberger B, Spragan D, Hashmi S, Morrison A, Thomasson A, Nazarian S, et al. Pregnancy-induced sensitization promotes sex disparity in living donor kidney transplantation. J Am Soc Nephrol. (2017) 28:302533. doi: 10.1681/ASN.2016101059

37. Pollack MS, Trimarchi HM, Riley DJ, Casperson PR, Manyari LE, Suki WN. Shared cadaver donor-husband HLA class I mismatches as a risk factor for renal graft rejection in previously pregnant women. Hum Immunol. (1999) 60:1150-5. doi: 10.1016/S0198-8859(99)00104-4

38. Wehmeier C, Georgalis A, Hirt-Minkowski P, Amico P, Hoenger G, Voegele T, et al. 2222 kidney transplantations at the University Hospital Basel: a story of success and new challenges. Swiss Med Wkly. (2016) 146:w14317. doi: 10.4414/smw.2016.14317

Conflict of Interest: The authors declare that the research was conducted in the absence of any commercial or financial relationships that could be construed as a potential conflict of interest.

Publisher's Note: All claims expressed in this article are solely those of the authors and do not necessarily represent those of their affiliated organizations, or those of the publisher, the editors and the reviewers. Any product that may be evaluated in this article, or claim that may be made by its manufacturer, is not guaranteed or endorsed by the publisher.

Copyright (C) 2021 Senn, Wehmeier, Hönger, Geiger, Amico, Hirt-Minkowski, Steiger, Dickenmann and Schaub. This is an open-access article distributed under the terms of the Creative Commons Attribution License (CC BY). The use, distribution or reproduction in other forums is permitted, provided the original author $(s)$ and the copyright owner(s) are credited and that the original publication in this journal is cited, in accordance with accepted academic practice. No use, distribution or reproduction is permitted which does not comply with these terms. 